\title{
Recent Updates on Marine Cancer-Preventive Compounds
}

\author{
Sergey A. Dyshlovoy
}

check for

updates

Citation: Dyshlovoy, S.A. Recent Updates on Marine Cancer-Preventive Compounds. Mar. Drugs 2021, 19, 558. https://doi.org/ $10.3390 /$ md19100558

Academic Editor: Marc Diederich

Received: 9 September 2021

Accepted: 24 September 2021

Published: 29 September 2021

Publisher's Note: MDPI stays neutral with regard to jurisdictional claims in published maps and institutional affiliations.

Copyright: (C) 2021 by the author. Licensee MDPI, Basel, Switzerland. This article is an open access article distributed under the terms and conditions of the Creative Commons Attribution (CC BY) license (https:/ / creativecommons.org/licenses/by/ $4.0 /)$.
Laboratory of Pharmacology, A.V. Zhirmunsky National Scientific Center of Marine Biology, Far Eastern Branch, Russian Academy of Sciences, 690041 Vladivostok, Russia; dyshlovoy@gmail.com

\begin{abstract}
The natural compounds derived from marine organisms often exhibit unique chemical structures and potent biological activities. Cancer-preventive activity is one of the rather new activities that has emerged and been extensively studied over the last decades. This review summarizes the recent updates on the marine chemopreventive compounds covering the relevant literature published in 2013-2021 and following the previous comprehensive review by Stonik and Fedorov (Marine Drugs 2014, 12, 636-671). In the current article, only the molecules having an effect on malignant transformation (or related pathway and molecules), cancer stem cells, or carcinogen-induced in vivo tumor development were considered to be "true" cancer-preventive compounds and were, therefore, reviewed. Additionally, particular attention has been given to the molecular mechanisms of chemoprevention, executed by the reported marine compounds.
\end{abstract}

Keywords: marine natural products; cancer-prevention; polyphenols; alkaloids; carotenoids; lipids; macrolides; terpenoids; peptides; polysaccharides

\section{Introduction}

Cancer is a complex genetic disease, which appears as the uncontrolled growth of cells, first resulting in tumor formation and further gaining an ability to invade other tissues and organs (i.e., to metastasize) [1]. This pathological condition is stipulated by the alterations in gene structure and expression caused by various exogenous and endogenous factors. According to the most recent WHO report, cancer takes around 10 million lives annually [2]. In recent decades, tremendous progress in the diagnosis and treatment of different types of neoplasms has been achieved. Despite this, cancer is still one of the leading causes of death, worldwide, and especially in developed countries [3]. One of the reasons is the mutational background of this disease, which results in a huge heterogeneity in genotype and phenotype of tumor cells within the same cancer type, and even within the same tumor, in a single patient [4]. Therefore, cancer treatment is a challenging process that requires the use of multiple expensive medications and techniques. Additionally, anticancer therapy very often requires the application of cytotoxic targeted or untargeted chemotherapeutics. These drugs are often toxic to normal non-cancer cells and/or exhibit other side effects unrelated to their cytotoxicity [5]. Therefore, the prevention of cancer, rather than its treatment, is a highly favorable scenario for both patients and health care systems.

The marine environment is characterized by special conditions, such as lack of sunlight and oxygen, high pressure and salinity, low stable temperatures, etc. [6,7]. This determines the specific biochemistry of sea inhabitants that frequently results in the production of unique metabolites by marine micro- and macro-organisms. These molecules often exhibit promising biological activity, and some of them can be used to prevent and cure human diseases [8,9] as well as food additives and cosmetic ingredients [10]. Thus, today there are 16 drugs, approved for in-patient use, that were created and developed from natural marine-derived molecules. A significant proportion of these drugs-11 out of 16-is used in the treatment of different types of human cancers [11,12]. Furthermore, there is an impressive variety of food supplements developed from the extracts and semi-purified fraction of edible marine organisms, which were reported to be beneficial for human 
health $[13,14]$. Many of them were assumed to have antioxidant, immunostimulatory, and cancer-preventive properties [13-18].

Apart from the marine-derived drugs approved by the European and US authorities, there are many reports that clearly indicate the correlation of dietary habits and cancer risk [19]. Thus, a higher consumption of seafood was associated with lower risk for different cancers, especially colorectal and gastric cancer [20-24]. Interestingly, certain marine organisms are widely used in the traditional folk medicine of many Asian countries for the treatment of different pathological conditions, including cancer $[25,26]$. Some of the bioactive molecules responsible for the above-described health-beneficial effects have been isolated and characterized; others are still awaiting investigation.

This review is based on a previous comprehensive review of the marine-derived small molecules exhibiting cancer-preventive properties, published in 2014, in Marine Drugs, by Stonik and Fedorov [27]. In that study, the authors analyzed papers from 2003-2013 that reported molecules exhibiting chemopreventive activity, in vitro or in vivo [27]. The current review covers the relevant literature published between June 2013 an September 2021 and gives the most recent updates on cancer-preventive marine compounds. Here, only the compounds capable of inhibiting malignant transformation in vitro or in vivo, and/or tumor formation in vivo, were assumed as cancer-preventive agents. Molecules for which only cytotoxic activity towards cancer cells has been reported were not considered cancerpreventive agents, but rather as chemotherapeutic compounds. Additionally, particular attention is given to their mechanisms of chemopreventive activity.

\section{Carcinogenesis and Its Prevention}

Data collected in recent decades clearly indicates cancer to be a very heterogeneous disease [4]. Every cancer type is genetically and biochemically different from each other, and therefore requires a specific therapeutic approach, or even better, a personalized treatment for every single patient [28,29]. The same is true for carcinogenesis. Thus, diverse alterations in different genes are involved in the genesis of various cancer types [30]. Moreover, different mechanisms may lead to the same oncogenic alteration in the same cell. However, there are three general steps of carcinogenesis that have been determined and described for the majority of tumors [31]:

Initiation: At first, a carcinogenic factor, e.g., a chemical agent, induces an irreversible (by forming DNA adducts) or reversible (epigenetic) modification of DNA or histones [1]. This may further lead to the mutation of DNA during its replication, the epigenetic promotion of oncogenes, or inhibition of tumor-suppressor gene activity [32].

Promotion: The affected cell is further divided, in order to expand the initiated clone and, therefore, to produce a larger population of cells bearing the genetic mutation acquired in the previous step. These cells have a higher risk of further genetic alterations and of consequent malignant transformation [1]. In this step, exposure to a tumor promoter is required. Normally, tumor promoters (e.g., phorbol ethers or epidermal growth factor (EGF)) themselves are not mutagens or carcinogens [33]. However, there are so-called "complete carcinogens" (e.g., benzo[a]pyrene) which are capable of both tumor initiation and promotion $[34,35]$.

Progression: In this step, the cells start to express the malignant phenotype, which is characterized by uncontrolled growth and genetic instability. Additionally, the cells are able to secrete proteases, which facilitates their ability to invade other tissues and organs, thereby forming metastases [36].

To prevent cancer means, therefore, to inhibit one of the above-described steps of carcinogenesis. However, the majority of chemopreventive agents acts at the initiation step, i.e., via a neutralization of the carcinogen (stimulus) or via an attenuation of its DNA-damaging action. Apart from the genetic background, which already includes already existing inherited gene mutations (germline mutations), the newly acquired mutations in the body cells (somatic mutations) may result from the exposure to three carcinogen types. This includes physical (UV, ionizing radiation [IR]); chemical (cigarette smoke, benzo[a]pyrene, asbestos, 
aflatoxin, some hormones and hormone-like molecules, and many others), and biological carcinogens (e.g., papillomaviruses, hepatitis B and C, Helicobacter pylori, etc.) [37]. Chemopreventive agents may suppress a carcinogen or its secondary effects via different mechanisms. These mechanisms include an inhibition of chronic inflammation, which was reported as a predisposition to several cancer types; scavenging of reactive oxygen species (ROS) and other free radicals, which result from UV, IR, or chemical exposure and leads to DNA damage; stimulation of the innate immunity in order to recognize and eliminate a malignant-transformed cells; inhibition of oncogenic nuclear factors such as NF-kB and AP-1; and many others [38-40].

Another aspect, which is especially important in the models utilizing chemical carcinogens, is an effect on the xenobiotics biotransformation system. Drug-metabolizing enzymes are classified into two main groups, namely, phase I and II enzymes [41]. In phase I, the xenobiotic to be metabolized undergoes oxidation, reduction, or hydrolysis, which results in more polar metabolites. Then, these molecules enter phase II to undergo consequential conjugation with the substrate; this results in a non-reactive polar compound, which could be easily excreted from the body $[42,43]$. The main detoxifying enzymes of phase I are the members of the cytochrome P450 (CYP) family, whereas phase II enzymes include glutathione-S-transferases, quinone-reductases, $\mathrm{N}$-acetyltransferases, sulfotransferases, methyltransferases, and others. Both phase I and II enzymes are located in the endoplasmic reticulum (ER). While the xenobiotics biotransformation (detoxification) system is supposed to neutralize toxic and harmful molecules, some chemicals, during this process, may form highly reactive and therefore carcinogenic compounds, e.g., epoxides, $\mathrm{N}$-oxides, etc. Particularly often, this happens during oxidation in phase I, resulting in genetoxic compounds, which, however, in most cases will be further neutralized in phase II. Therefore, compounds capable of phase I-enzyme inhibition and phase II-enzyme promotion are often consideredchemopreventive agents; and it has been experimentally proven for a number of molecules. At the same time, it should be noted that phase II enzymes do not exclusively play a protective role and sometimes may also activate a carcinogen [44]. Thus, the above-mentioned assumption should be carefully examined in each particular case [45].

\section{Polyphenols}

Several studies have reported a cancer-preventive effect of marine polyphenols. These compounds are often isolated from a brown algae and have exhibited an impressive spectra of biological activities, including antioxidant and anti-tumor properties [46-48]. Previously, it has been reported that an extract of a brown alga Ecklonia stolonifera may attenuate a DMBA-induced chromosomal aberration [49]. Later, an anti-photocarcinogenic effect of the brown algae polyphenols has been reported in UVB-induced skin carcinogenesis in SKH-1 mice and suggested to be associated with an inhibition of pro-inflammatory COX-2 [50].

Recently, a comprehensive in vivo-based study by Xiao et al. has reported chemopreventive properties of the phlorotannin dieckol (Figure 1) [51]. This marine polyphenol was isolated from a brown alga Ecklonia cava (belonging to Lessoniaceae family) and has been tested in a DMBA-induced skin cancer model in vivo. Thus, a daily dieckol treatment could significantly reduce a DMBA-induced tumor incidence, tumor volume, as well as tumor burden. The mechanism of action has been defined as (i) an inhibition of IkB/NF-kB signaling, (ii) reduction of inflammatory processes (i.e., suppression of IL-6, IL-1 $\beta$ and TNF- $\alpha$ ), and (iii) antioxidant activity. The later was exerted via the induction of antioxidant enzymes (SOD, CAT, GPx) as well as increase of the glutathione level and a simultaneous inhibition of cytochromes p450 and b5 (phase-I detoxification enzymes). Additionally, an induction of pro-apoptotic (p53, Bax, caspase-3 and -9) and inhibition of anti-apoptotic (Bcl2 , COX-2, and TGF- $\beta 1$ ) genes at transcriptional level has been detected in the drug-treated cells, suggesting dieckol promotes tumor cells apoptosis [51]. Of note, the antioxidant activity has been recently reported to be a major mechanism of the hepatoprotective activity 
of dieckol and related compounds in several liver damage models [52,53]. Thus, the hepatoprotective activity of dieckol has been reported in a tetrachloromethane-induced in vivo model. It was suggested to be exerted via an activation of antioxidant enzymes as well as via the anti-apoptotic activity of dieckol in hepatocytes [54,55]. One can suggest that the above-mentioned effect may also result in cancer-preventive properties of dieckol and other marine polyphenols in the chemical agents-induced liver injury models. Indeed, the study by Sadeeshkumar et al. published in 2017 has reported an in vivo chemopreventive activity of dieckol in rats in the model of N-nitrosodiethylamine-induced hepatocarcinoma [56]. The authors have shown dieckol to suppress the carcinogen-activated phase I enzymes (cytochrome P450, CYB5A, CYB5R, and CYPOR) and simultaneously increase an activity of phase II enzymes (GST and QR) therefore promoting a N-nitrosodiethylamine detoxification [56]. This marine polyphenol induces an apoptosis of malignant transformed cells (executed via intrinsic pathway) and inhibits MMP-2/9 and VEGF expression at both, mRNA and protein levels. Additionally, an inhibition of pro-inflammatory factors NF-kB and COX-2 has been detected. Based on these results the authors have speculated that dieckol may suppress angiogenesis, cancer cells invasion, and the carcinogen-induced inflammatory processes; however, in the current research these effects have not been further investigated [56].

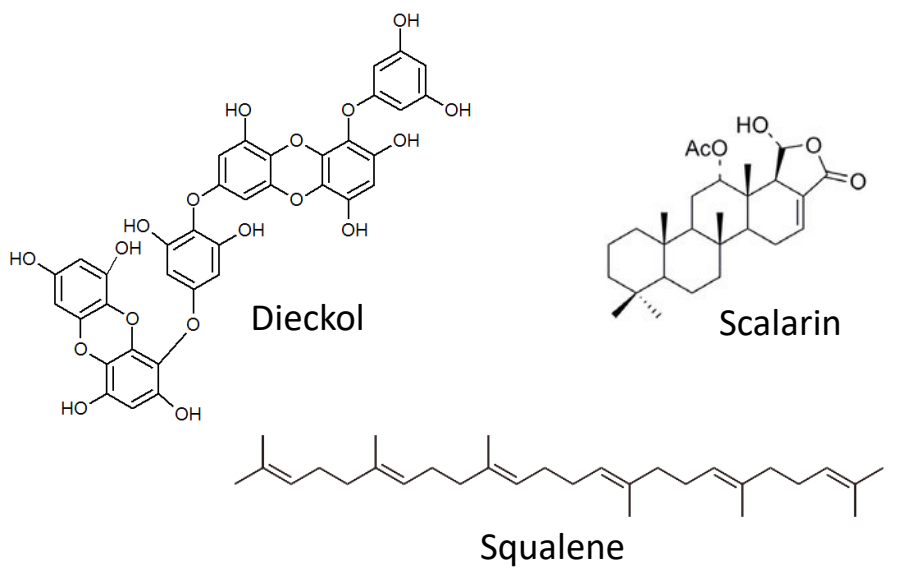<smiles>COC(CC/C=C/CCCCC(=O)CCCCC(=O)CCCCCCCCCO)C(=O)NCCc1ccc(O)cc1</smiles>

Melonosin A<smiles>CO[C@H](CC/C=C/CCCC(=O)CCCCC(=O)CC/C=C/CCCCCCO)C(=O)NCCc1ccc(O)cc1</smiles>

Melonosin B<smiles>COC1=CC(=O)N(C(=O)[C@H](OC(=O)C2CCCN2C(=O)C2CCCN2C(=O)C(C(C)C)N(C)C(=O)[C@@H](NC(=O)C(C(C)C)N(C)C)C(C)C)C(C)C)C1Cc1ccccc1</smiles>

Dolastatin 15

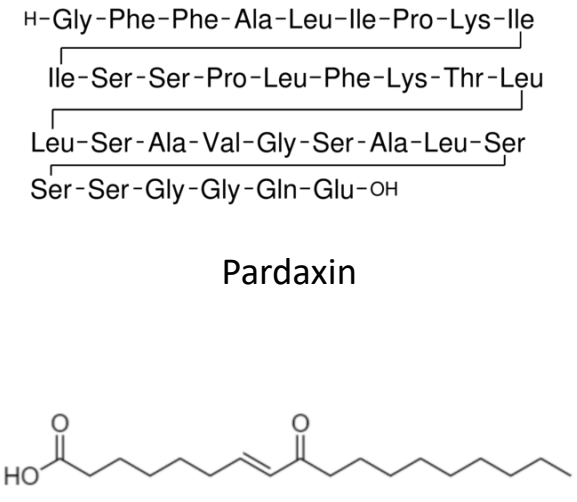

7(E)-9-keto-octadec-7-enoic acid (keto-type C18 fatty acid)<smiles>CCCCCCCC(=O)/C=C/CCCCCC(=O)O</smiles>

7(E)-9-keto-hexadec-7-enoic acid (keto-type C16 fatty acid)<smiles>CCCCCCCCCCCC(=O)/C=C/CCCCCC(N)=O</smiles>

7(E)-9-keto-octadec-7-enamide (amide derivative of keto-type C18 fatty acid)

Figure 1. Marine cancer-preventive compounds: polyphenols, terpenoids, lipids and peptides.

\section{Terpenoids}

In 2020 Rajamani and colleagues reported a cancer-preventive effect of squalene (Figure 1) in the $\mathrm{KBrO}_{3}$-induced renal cell carcinoma model in vivo in rats [57]. Squalene is a triterpene isolated from brown algae and known to have potent medical properties $[58,59]$. 
The mechanism of its activity has been described as inhibition of multiple ROS-inducing factors as well as suppression of inflammatory, metastatic and survival processes. Thus, squalene could suppress HIF signaling in both VHL-wild type and VHL-mutant renal cell carcinoma, as well as inhibit a NF-kB-mediated inflammation. Additionally, it could decrease VEGF localization and a micronucleus frequency in polychromatic erythrocytes [57]. Even though no actual tumor formation has been detected in $\mathrm{KBrO}_{3}$-treated control rats, the above reported effects of squalene strongly suggest its chemopreventive activity in renal cell carcinoma executed via multiple mechanisms.

The receptor of advanced glycation end products (RAGE) is known to promote stress and survival as well as inflammatory pathways. This can lead to carcinogenesis, therapy resistance, proliferation and metastatic potential of pancreatic cancer cells [60]. Therefore, RAGE inhibitors have chemopreventive potential. Guzman et al. have shown that scalarin (Figure 1), a bioactive metabolite of the marine sponge Euryspongia cf. rosea, is able to inhibit a RAGE activity in pancreatic cancer cells and therefore may have chamopreventive properties $[61,62]$. The upcoming experiments should clarify this in the near future.

\section{Lipids}

In 2018 the group of Makarieva has reported an isolation of two new marine lipidsnamely, melonoside $\mathbf{B}$ and melonosins A and $\mathbf{B}$ (Figure 1) from the marine sponge Melonanchora kobjakovae [63]. These molecules have been characterized as unusual lipids containing $\omega$-hydroxy fatty acid amides. The authors have reported melonosins A and B to be capable of inhibition of oncogenic nuclear transcriptional factors AP-1 or NF-kB in JB6 Cl41 cells at noncytotoxic concentrations [63]. The observed effects have occurred independently from the p53 activity. Notably, in the model of JB6 Cl41 cells the activity of AP-1 and NF-kB has been previously reported to be critical for the EGF-promoted neoplastic transformation [64]. Hence, inhibitors of these nuclear factors may be considered potential cancer-preventive agents [64]. However, in the current study no further confirmatory experiments have been performed [63].

The Luesch et al. studied compounds capable of activating the cytoprotective Nrf2ARE pathway [65]. This pathway, which is involved in the neutralization of ROS, is executed via induction of the antioxidant-response element (ARE). ARE controls and modulates a number of phase II detoxification enzymes [66]. Therefore, the small molecules capable of ARE-activation can be considered promising cancer-preventive agents. Using the ARE activity-guided fractionation, the authors have reported an isolation of three new monounsaturated fatty acids (MUFAs) from an edible green alga, Ulva lactuca [65]. Namely, an isolation of keto-type C18 fatty acid, keto-type C16 fatty acid, and the amide derivative of keto-type C18 fatty acid (Figure 1) has been reported. The keto-type C18 fatty acid could increase the expression of cytoprotective genes regulated by ARE (i.e., NADPH:quinone oxidoreductase 1, heme oxygenase 1, thioredoxin reductase 1, glutamatecysteine ligase subunits, and the cystine/glutamate exchange transporter). The AREactivation effect of the compound and the consequent induction of the ARE-controlled gene expression has also been observed, in vivo, in mice models [66]. The authors speculate that this is due to the ability of the isolated keto-type C18 fatty acid to stabilize Nrf2 via inhibition of its Keap1-mediated ubiquitination, which therefore leads to Nrf2 accumulation and translocation to the nucleus [65].

The Li et al. reported the chemopreventive effect of $\mathbf{n}-\mathbf{3}$ polyunsaturated (omega-3) fatty acid (Figure 1) (fish oil) diet in an DMBA-induced mammary gland cancer murine model, in vivo [67]. Thus, it was shown that a n-3 polyunsaturated fatty acid-rich diet during pregnancy reduces the risk of breast cancer in the offspring. This effect is related to the reduction of $17 \beta$-estradiol (E2) in both pregnant animals as well as female offspring. Additionally, the mechanism of action has been identified as the promotion of the p53 pathway and the inhibition of oncogenic NF-kB and JAK-STAT signaling [67]. The main compounds suggested to be responsible for the above-described activity are eicosapentaenoic acid (EPA) and docosahexaenoic acid (DHA). 


\section{Peptides}

Pardaxin (Figure 1) is a marine-derived antimicrobial polypeptide (H-GFFALIPKIISSP LFKTLLSAVGSALSSSGGQE-OH), which was isolated from the oceanic fish Pardachirus marmoratus (reviewed in [68]). Han et al. have studied a chemopreventive effect of this molecule in oral squamous cell carcinoma (OSCC) models [69]. Using a hamster buccal pouch model, they have shown that pardaxin administration can inhibit DMBAinduced carcinogenesis in vivo [69]. This effect is partially explained by the detected dosedependent inhibition of prostaglandin E2 (PGE2) level, which are elevated in DMBA-treated animals and, therefore, by the inhibition of pro-inflammatory COX-2/PGE2 signaling. Additionally, the authors have shown that pardaxin induces a G2/M-phase cell-cycle arrest and the apoptosis of OSCC cells in vitro, which may also contribute to the cancer-preventive activity of this marine peptide [69].

The Sanyal et al. have studied the molecular mechanism of the chemopreventive action of the mollusk linear peptide dolastatin 15 (Figure 1) isolated from the sea hare Dolabella auricularia (but actually produced by cyanophytes that are part of the mollusk's diet), in combination with the COX-2 inhibitor celecoxib [70]. Previously, the same group has reported, in vivo, the cancer-preventive effect of the same marine peptide in a 1,2dimethylhydrazine (DMH)-induced rat model of colon carcinogenesis [71]. The authors explained the observed effect by Bcl-2's active site-targeting accompanied by the downregulation of its expression. Additionally, the up-regulation of pro-apoptotic Bax, Apaf- 1 , cytochrome $\mathrm{C}$, caspases, p53, and p21 was reported to play a role in this effect [71]. In a more recent study, the authors have further investigated the chemopreventive mechanisms of the drug combination, using the same model, and have reported an inhibition of the PI3K/AKT pathway by this drug combination [70]. This effect was achieved due to the targeting of the ATP binding sites of both PI3K and AKT. Additionally, treatment with dolastatin 15 plus celecoxib resulted in the increase of GSK-3 $\beta$, pro-apoptotic Bad, PTEN, and transcription factor Egr-1, the downregulation of cyclin D1, as well as increased intracellular calcium and oxidative stress. This ultimately led to mitochondrial membrane-potential drop-down and the apoptotic death of colon epithelial cells exposed to the carcinogen [70].

\section{Carotenoids}

Fucoxanthin (Figure 2) is a marine-derived carotenoid isolated from different brown alga species. Previously, this compound was reported to exhibit anticancer properties [72]. As many brown algae are consumed in food, the prevention of cancers of gastro-intestinal and colorectal system with fucoxanthin is of particular interest. In the recent years, a tremendous progress on the cancer-preventive activities of fucoxanthin and related compounds has been achieved by the Terasaki group. Recently, Terasaki et al. have reported the in-vivo cancer-preventive activity of this marine carotenoid in a colorectal carcinoma model [73]. The authors have speculated that an alteration of the gut microbiome plays a critical role in chemopreventive effect of fucoxanthin. In this model, an inflammationassociated carcinogenesis was initiated in the mice treated with azoxymethane/dextran sodium sulfate (AOM/DSS). Hence, in animals exposed to a carcinogen, treatment with fucoxanthin could reduce colorectal adenocarcinoma multiplicity. In line with this, the number of apoptosis-prone caspase-positive cells was increased in both colonic adenocarcinoma and mucosal crypts [73]. Interestingly, it has been noted that treatment with fucoxanthin led to the inhibition of Bacteroidlales spp. and Rikenellaceae spp. and, at the same time, promoted Lachnospiraceae spp. in gut microbiota. Remarkably, the authors have shown that administration of Lachnospiraceae spp. (achieved via gavaging, with suspension, the feces of mice receiving fucoxanthin) reduced a number of colorectal adenocarcinomas in carcinogen-exposed mice. Based on this, the conclusion of a critical role of the gut microbiome in the anticancer effect of fucoxanthin in inflammation-associated colorectal carcinoma has been made. 
<smiles>CC(=O)OC1CC(O)[C@](C)(/C=C/C(C)=C/C=C(C)/C=C(C)/C=C/C=C(C)/C=C/C=C(\C)C(=O)CC2C(C)CC(O)CC2(C)C)C(C)(C)C1</smiles>

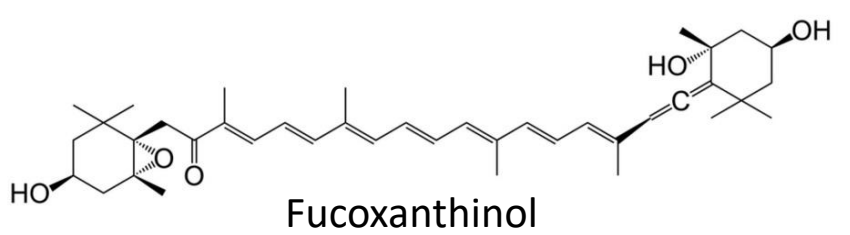

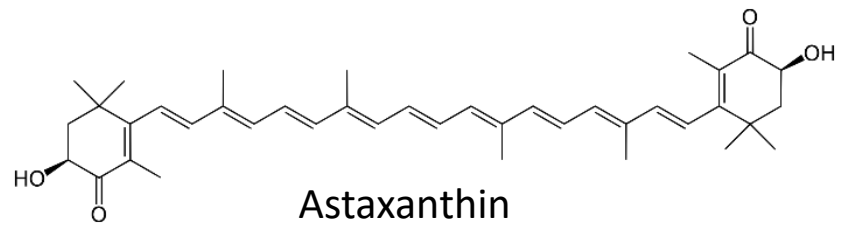

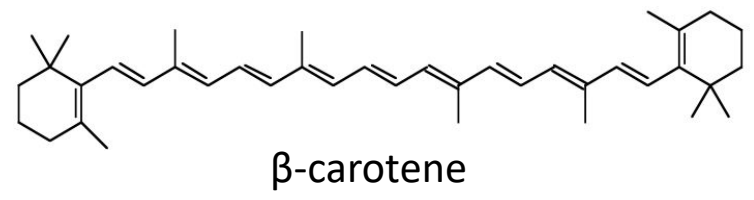<smiles>CC1=CC(O)CC(C)(C)C1/C=C/C(C)=C/C=C/C(C)=C/C=C/C=C(C)/C=C/C=C(C)/C=C/C1=C(C)CC(O)CC1(C)C</smiles>

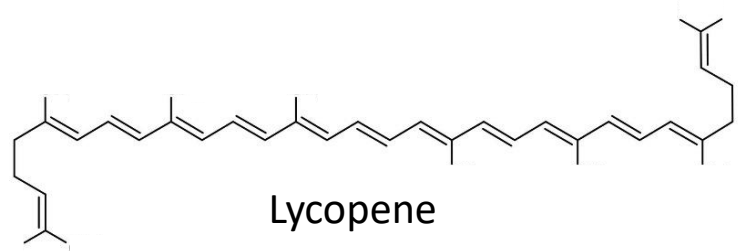

Figure 2. Marine cancer-preventive compounds: carotenoids.

Earlier, in 2017, the same group reported the cancer-preventive effect of fucoxanthinol (Figure 2), which is an intestinal metabolite of fucoxanthin [74]. Notably, orally consumed fucoxanthin undergoes a deacetylation in the small intestine (under action of intestinal esterases), which results in fucoxanthinol. This has been observed in both mice and humans $[74,75]$. The authors have examined the effect of fucoxanthinol on colorectal cancer stem cells (CCSCs). Cancer stem cells (CSC) are tumorigenic cells that can persist in tumors and, due to their distinct properties, are often unaffected by chemotherapy. Therefore, CSC may later give rise to relapsed tumors and metastases [76]. Hence, compounds capable of killing CSC can be considered chemopreventive agents [77]. In this research, fucoxanthinol was capable of suppressing the growth of several CCSCs cell lines or CCSC-like cells in vitro and in vivo, presumably via the inactivation of Akt (inhibition of $\mathrm{p}-\mathrm{Akt}$ ), and the down-regulation of PPAR $\beta / \delta$ and PPAR $\gamma$ proteins. In ta CCSCs mice xenograft model, fucoxanthinol was able to slow down tumor progression. Therefore, the cancer-preventive properties of fucoxanthin administrated orally (e.g., via a brown alga-rich diet) in related models could, at least in part, be explained by the activity of its intestinal metabolite fucoxanthinol [74].

Very recently, in 2021, the Terasaki group characterized an effect of fucoxanthinol (Figure 2) on pancreatic ductal adenocarcinoma cancer cells, generated from a Syrian golden hamster exposed to $\mathrm{N}$-nitrosobis(2-oxopropyl)amine [78]. The generated cell lines were characterized as papillary adenocarcinoma, well-differentiated tubular adenocarcinoma, moderately differentiated tubular adenocarcinoma, and poorly differentiated adenocarcinoma. Fucoxanthinol was able to effectively suppress the growth of all these cells. This effect was stipulated by the inhibition of cell cycles, chemokine and integrin levels, the suppression of actin polymerization, and the disruption of microtubule organization [78]. The treatment led to the inhibition of PI3K/AKT and TGF- $\beta$ signaling pathways, and ultimately resulted in cell death via simultaneous apoptosis and anoikis. Thus, fucoxanthinol could eliminate the cells that underwent malignant transformation, which was considered a chemopreventive effect.

In 2017 the same group reported fucoxanthinol (Figure 2) to induce anoikis (an anchorage-dependent apoptosis) in human colorectal cancer ecells in vitro th via inhibition of both integrin $\beta 1$ signaling and focal adhesion kinase (FAK) [79,80]. More recently, in 2019 and 2020 Terasaki et al. have shown, in vivo, anoikis to be a mechanism of fucoxanthin cancer-preventive activity in a model of AOM/DSS-induced colon carcinogenesis [79]. Thus, a fucoxanthin-rich diet suppressed the number and size of polyps in the mice ex- 
posed to AOM/DSS as well as reduced the rate of colonic lesions and their multiplicity. The incidence and multiplicity of colonic adenocarcinoma was also reduced in mice receiving fucoxanthin. In line with these results, the suppression of such anoikis markers as integrin $\beta 1$, p-FAK, p-paxillin, and the simultaneous caspase-3 activation was observed in the fucoxanthin-treated group. However, this effect was more pronounced in colonic adenocarcinoma cells in comparison with colonic mucosal crypts cells $[79,80]$. Thus, an induction of cancer epithelial cells anoikis was postulated as the main mechanism of fucoxanthin's chemopreventive action in colon carcinogenesis models [80].

Astaxanthin (Figure 2) is another carotenoid found in various marine organisms [81]. Han et al. have reported its inhibitory effect on Helicobacter pylori-induced inflammation and oncogenesis in gastric mucosal tissues of mice [82]. The experiments were performed in in vivo models. H. pylori is a well-known risk factor of pancreatic cancer. Prolonged exposure of gastric epithelium cells to this bacterial infection results in long-term inflammation which may lead to carcinogenesis [83]. The astaxanthin-supplemented diet attenuates an $H$. pylori infection-induced activation of myeloperoxidase, expression of lipid peroxide, proinflammatory cytokine IFN- $\gamma$ and c-myc oncogene as well as an expression of cyclin D1 [82]. Therefore, astaxanthin could protect gastric mucosal tissues from inflammatory and oncogenic responses as well as from the oxidative damage resulting from gastric H. pylori infection. Further studies should uncover the actual chemopreventive effect of astaxanthin and other marine carotenoids in the prevention of gastric cancer.

Srinivasan and colleagues have reported the cancer-preventive effect of alyophilized carotenoids-rich Dunaliella salina extract, administrated as a food supplement, in a mammary cancer model in vivo [84]. In this research, female Wistar rats were treated with DMBA in order to induce mammary carcinoma. The treatment with the Dunaliella salina extract was able to decrease the levels of hormonal receptors relevant for the progression of breast cancer (such as ER, PR and HER2), inhibit cell proliferation, down-regulate the expression of pro-inflammatory COX-2 and induce apoptotic markers. The investigated extract was also shown to be able to revert the activities of antioxidant enzymes and phase-II detoxification enzymes (which were suppressed under the DMBA treatment), as well as phase-I detoxification enzyme (activated under the DMBA treatment) [84]. Ultimately, the treatment with lyophilized $D$. salina extract has resulted in reduction of tumor incidence rate and tumor volume in the carcinogen-exposed animals. HPLC analysis of the extract identified $\beta$-carotene, lutein, and lycopene (Figure 2) to be the main molecules presumably responsible for its chemopreventive properties [84]. The precise composition of the extract, however, has not been established.

\section{Macrolides}

Murphy et al. reported isolating of a new macrolide, juvenimicin C (Figure 3), from the marine bacterium Micromonospora yangpuensis [85]. Juvenimicin $C$ was able to induce the phase-II enzyme quinone reductase 1 (QR1). This enzyme is responsible for twoelectron detoxification and reduction of exogenous xenobiotics and carcinogens as well as endogenous ROS. Therefore, its activation is considered a marker of chemopreventive agents [86]. Additionally, juvenimicin $C$ activated glutathione reductase, glutathione peroxidase and induced intracellular levels of glutathione. However, no further experiments confirming this suggested cancer-preventive activity have been performed. 


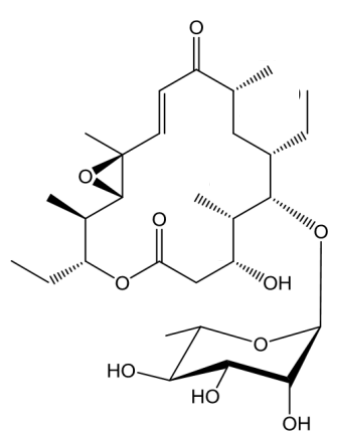

Juvenimicin C<smiles>COC1=C(Br)[C@@H](O)[C@](O)(CC#N)C=C1Br</smiles>

Aeroplysinin-1

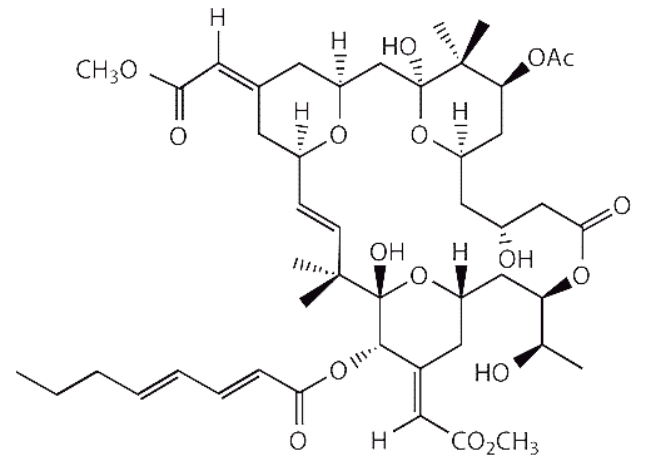

Bryostatin-1<smiles>O=C1Nc2cc(Br)ccc2C1=O</smiles>

\section{6-Bromoisatin}<smiles>CC1=Nc2cc(Br)ccc2C1=O</smiles>

Tyrindoleninone<smiles>CCC(C)CCCCCC(=O)NC(C(=O)NC1CCNC1=O)C(C)C</smiles>

Svalbamides A<smiles>CCC(C)CCCC[C@H](O)CC(=O)N[C@H](C(=O)N[C@H]1CCNC1=O)C(C)C</smiles>

Svalbamides B

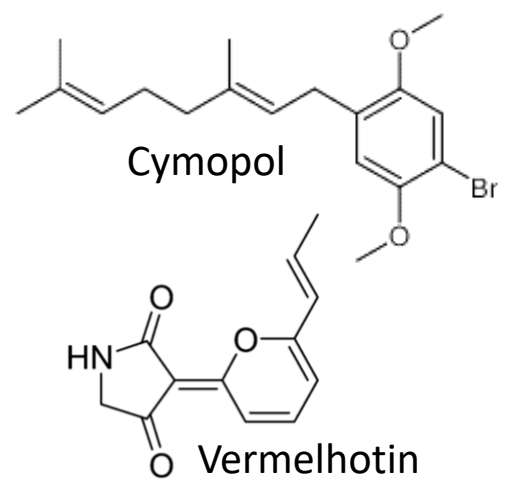<smiles>C/C=C(\C)C(=O)C[C@H]1C2=COC(/C=C/C[C@H](C)O)=CC2=C(Cl)C(=O)C1O</smiles><smiles>C/C=C(\C)C(=O)C[C@H]1C2=COC(/C=C/[C@@H](C)[C@H](C)O)=CC2=C(Cl)C(=O)[C@H]1O</smiles>

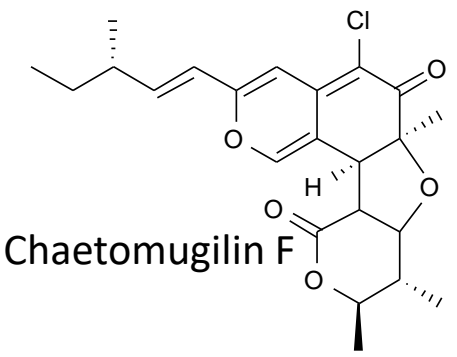

Figure 3. Marine cancer-preventive compounds: macrolides, alkaloids and other molecules.

Another well-known marine macrocyclic lactone, bryostatin-1 (Figure 3), of bacterial origin and previously isolated from bryozoan Bugula neritina [87], has been examined for its chemopreventive properties by Salim and colleagues [88]. In this study, an association between chronic Syphacia muris parasite infection and 1,2-dimethylhydrazine (DMH)induced colorectal carcinogenesis was been examined, in vivo, in a rat model. The authors have shown that treatment with bryosatin-1 reduced the formation of DMH-induced aberrant crypt foci. Additionally, histological examination has revealed a pronounced inhibition of the IgM, Ki67 and caspase-3 expression in the colorectal epithelium as well as serum IgM and IgG of the animals receiving bryosatin-1. The treatment has restored antioxidant properties of the cells. Finally, it has been shown that a DMH-treatment combined with a $S$. muris infection provoked an upregulation of pro-inflammatory COX2 and simultaneously resulted in down-regulation of the tumor-suppression $A P C$ gene mRNAs in colorectal mucosa. Bryostatin-1 could reduce these above described negative effects (oxidative stress, inflammation, and antiapoptotic factors), which ultimately resulted in the reduction of the colorectal carcinogenesis [88]. 


\section{Alkaloids}

Another two potent small molecules capable of a QR1 enzyme induction are svalbamides A and B (Figure 3). These alkaloids were isolated by Du et al. from the sedimentderived arctic bacterium Paenibacillus sp. [89]. Svalbamides A and B could activate QR1 at their non-cytotoxic concentrations in the murine hepatoma model (Hepa1c1c7 cells), and therefore were suggested to be chemopreventive agents [89]. Though, no further validation experiment has been performed.

Park et al. have reported the cytotoxic activity of aeroplysinin-1 (Figure 3) in colon cancer in vitro [90]. Aeroplysinin-1 is a brominated small molecule isolated from the marine sponge Aplysina sp. [91]. The authors described the anti-proliferative activity of aeroplysinin- 1 in DLD- 1 cells due to the attenuation of Wnt/ $\beta$-catenin signaling exerted via promotion of $\beta$-catenin degradation [90]. It is known that the development of colorectal cancer is associated with mutation in the adenomatous polyposis coli (APC) gene. This mutation leads to accumulation of a nuclear $\beta$-catenin and ultimately results in the expression of a number of genes involved in colorectal tumorigenesis, tumor development and metastasis [92-94]. Thus, the degraders of $\beta$-catenin may have a potential cancer-preventive function. Indeed, aeroplysinin-1 treatment has promoted elimination of colorectal cancer cells, although no actual chemopreventive activity has been reported for this compound [90].

Esmaeelian and colleagues have studied the chemopreventive effect as well as the side effects of the brominated indoles tyrindoleninone and 6-bromoisatin (Figure 3) in vivo [95]. These compounds were previously isolated from an Australian marine mollusk, Dicathais orbita, by the same group [96]. The effect was evaluated using the azoxymethane (AOM)-stimulated early-stage colon cancer model in C57BL/6 mice. In this model, daily oral administration of both tyrindoleninone and 6-bromoisatin as well as crude Dicathais orbita extract enhanced an apoptosis of the epithelial colon cells exposed to the carcinogen (AOM). Notably, in this study, the authors used a 6-h short-term treatment with AOM, thus no actual tumor formation could be observed in either group. Despite this, since AOM is an established genotoxic agent with carcinogenic properties [97], the authors have concluded that in a long-term exposure model, treatment with the isolated brominated indoles may result in an antitumorigenic effect [95]. Further validation studies confirming this speculation are warranted.

Hwang and colleagues have reported the photoprotective activity of the marine alkaloid topsentin (Figure 3) in human keratinocyte HaCaT cells [98]. Topsentin is a bis(indole)alkaloid isolated from the marine sponge Spongosorites genitrix [99]. It was shown that topsentin suppresses expression of UBV-induced pro-inflammatory COX-2 and prostaglandin E2 (PGE2), as well as the downregulation of AP-1 activity and MAPK signaling. Additionally, topsentin suppressed expression of the miRNA, miR-4485, and subsequently inhibited TNF-IP2 and TNF- $\alpha$ in UVB-irradiated keratinocytes. It has been previously postulated that inflammatory processes as well as the activation of MAPK and especially of AP-1 nuclear factor may contribute to the malignant transformation of epithelial skin cells [100-102]. Therefore, based on the generated results, the authors speculate that topsentin has a photoprotective effect and, consequently, may protect the skin from UVB-induced cancer. Further experiments are required to confirm this suggestion.

The Kittakoop group described an in vitro anti-inflammatory activity of the marine alkaloid vermelhotin [103]. This compounds has been previously isolated from the marinederived fungi Nodulisporium sp. and CRI247-01 [104]. The authors have shown vermelhotin to inhibit NO production in LPS-stimulated macrophages. This effect has been exerted by the selective inhibition of p38 kinase, which resulted in inhibition of iNOS expression [103]. The generated data suggests vermelhotin to have an anti-inflammatory activity, which may also result in prevention of several cancer types as it has been described above. However, this speculation should be further confirmed experimentally. 


\section{Polysaccharides}

Kokoulin et al. isolated and characterized a new sulfated D-fucan from the marine bacterium Vadicella arenosi $\mathrm{KMM} 9024^{\mathrm{T}}$ [105]. The structure of polysaccharide was identified as a regular $\alpha-(1 \rightarrow 3)$-linked D-fucan sulfated at position O-2 of fucopyranosyl residues; it has been reported as the very first sulfated fucan found in bacteria [105]. The authors have reported the in vitro cancer-preventive activity of this molecule. Thus, the isolated polysaccharide could inhibit a malignant transformation of JB6 $\mathrm{P}^{+} \mathrm{Cl} 41$ murine cells. These cells are able to undergo the EGF-induced malignant transformation and consequently to form anchorage-independent colonies in soft agar; therefore, this well-established model is widely used for identification of cancer-preventive agents [106].

The same in vitro model of chemopreventive activity evaluation was utilized by Vishchuk at al., who studied te anticancer activities of fucoidans isolated from three brown algae, namely Saccharina cichorioides, Undaria pinnatifida, and Fucus evanescens (Figure 4) [107]. Fucoidans are sulfated polysaccharides found in brown algae and which exhibit a number of biological activities. In this study the authors have shown that highly sulfated $(1 \rightarrow 3)$ - $\alpha$-L-fucan from $S$. cichorioides demonstrates the most pronounced cancerpreventive activity in the model of EGF-induced malignant transformation of JB6 $\mathrm{P}^{+} \mathrm{Cl} 41$ cells [106]. Additionally, the authors have shown isolated fucoidans to have an inhibitory effect on anchorage-independent colony formation from the single cell, which have already undergone a malignant transformation. Such activity has been shown in human colon and breast cancer, as well as in melanoma models [107].

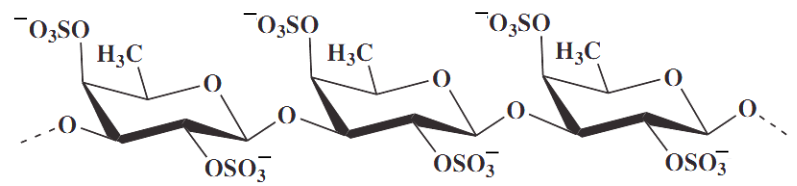

Fucoidan from Saccharina cichorioides
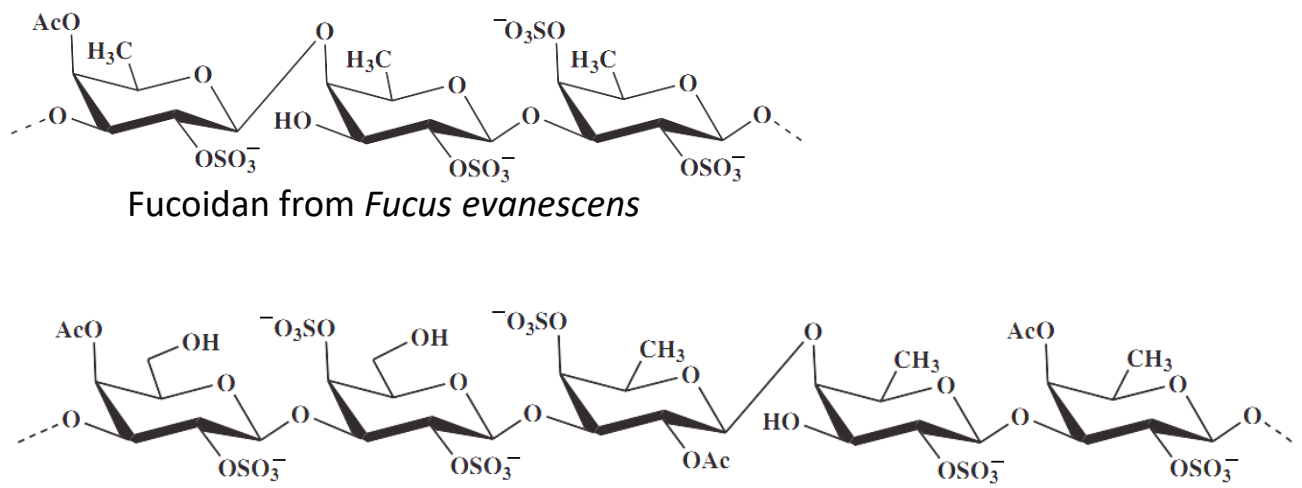

Fucoidan from Undaria pinnatifida

Figure 4. Marine cancer-preventive compounds: polysaccharides.

The Zhu et al. reported the cancer-preventive activity of te marine polysaccharide fucoidan, isolated from the brown alga Fucus evanescens [108]. This cancer-preventive activity has been shown in the above-mentioned JB6 $\mathrm{P}^{+} \mathrm{Cl} 41$ cell model. The authors suggest TOPK kinase to be one of the direct targets of fucoidan, and have therefore speculated its chemopreventive activity to be exerted via an inhibition of TOPK/ERK/MSK1 signaling. In line with this, fucoidan was able to inhibit colon cancer tumor growth in a mice xerograph model, which was stipulated by the inhibition of TOPK activity in the tumor tissues [108].

A fraction of sulfated polysaccharides from Ulva lactuca has been studied for its chemopreventive activity in the hepatocarcinoma (HCC) rat model [109]. In this model, 
HCC was initiated in rodents by diethylnitrosamine and then further promoted by phenobarbital treatment. The authors have shown that the treatment with the sulfated polysaccharides fraction of $U$. lactuca reduces toxin-induced oxidative injury of the liver due to the modulation of several enzymatic and non-enzymatic (e.g., direct scavenging of ROS) hepatic antioxidant defense pathways. Additionally, this fraction inhibits abnormal proliferation of the cells and induction of apoptosis of the malignantly transformed and fast proliferating cells, therefore exhibiting a chemopreventive activity [109].

\section{Other Molecules}

The Chang group reported an isolation of the previously known compounds 11-epi-chaetomugilin I, chaetomugilin I, and chaetomugilin F (Figure 3) from endophytic fungus Chaetomium globosum [110], which has been described as a symbiotic microorganism associated with several marine macroorganisms (reviewed in [111]). These molecules have been previously described by other groups [112-114]. The compounds could inhibit the (TNF- $\alpha$ )-induced NF- $\mathrm{BB}$ activity in HEK293 cells at their low micromolar non-cytotoxic concentrations. Based on this data, cancer-preventive properties of these compounds have been proposed, however, no further experiments confirming this activity have been performed [110].

Recently, Luesch et al. published a comprehensive study reporting the in vivo antiinflammatory effect on cymopol (Figure 3) [115]. Cymopol, a brominated phenolic compound isolated from a marine green alga Cymopolia barbata, was able to increase the antioxidant status of the intestine cells via modulation of antioxidant response mediated via transcription factor Nrf2. This activatory effect was achieved via direct interaction of cymopol quinone, a bioactiveted cymopol metabolite, and cysteine residues Keap1, which is known to be a cytoplasmic repressor protein of Nrf2 factor. Furthermore, cymopol was able to inhibit inflammatory gene transcription in vitro in macrophages and fibroblasts, which appeared to be executed via an Nrf2-dependent pathway. In addition to the antioxidant effect, cymopol has shown anti-inflammatory properties in vivo in the DSS-induced inflammatory model. Finally, the investigation of mucosal-associated microbiome demonstrated some effects that may be beneficial for treatment of various diseases, thereby producing possible polypharmacological effects [115]. Since these antioxidant and anti-inflammatory effects have been of critical importance in the prevention of colorectal cancer, cymopol and related compounds have been suggested to have a chemopreventive activity. This speculation awaits further experimental validation.

\section{Mixtures and Extracts}

The chemopreventive activities of the extracts of two edible algae-the green alga Capsosiphon fulvescens and the brown alga Hizikia fusiforme-have recently been reported [116]. These algae are widely used as a food supplement as well as in traditional folk medicine in Asian countries. The Jeong group described cancer-preventive properties of these extracts in vivo in a model of azoxymethane-induced colorectal cancer in rats [116]. The diet supplemented with these extracts has resulted in reduction of aberrant crypt-foci formation as well as in decreased proliferating cell nuclear antigen labeling index in the colonic tissues. However, no chemical composition analysis of the extracts has been done. Due to the antioxidant properties of the extracts, the authors have suggested that the mechanism of their cancer-preventive activity can be a P450 2E1 (CYP2E1) pathway inhibition; however, no validation experiments have been performed [116].

Osuna-Ruiz et al. have studied the extracts of green and brown algae S. filamentosa, $\boldsymbol{R}$. riparium and $\boldsymbol{C}$. sertularioides collected from Sinaloa (Mexico) [117]. The authors speculate that these extracts exhibit cancer-preventive properties due to their antioxidant, antiproliferative and antimutagenic activities. Additionally, the authors have hypothesized that flavonoids and chlorophylls may be active compounds responsible for these reported chemopreventive properties. However, no further experiments confirming this suggestion were performed in this study. More recently, the same group investigated the 
composition of the studied extracts [118]. The authors speculate polyunsaturated fatty acides, lutein, chlorophylls as well as $\beta$-sitosterol to be the main components responsible for the previously reported chemopreventive properties of the extracts [118].

Burgos Hernández et al. suggest that the fractionated hexane and methanol extract of octopus Paraoctopus limaculatus contained molecules capable of a chemoprotective activity $[119,120]$. A chemical analysis of the extract revealed the presence of compounds containing double bonds as well as oxygenated molecules (alcohols, ketones, and ethers). The authors have made this speculation based on itsantimutagenic activity, which was detected in the bacterium-based assay with aflatoxin B1 as a mutagen. Additionally, an antiproliferative activity in murine B-cell lymphoma cells and an antioxidant activity in cell-free assay have been reported $[119,120]$. However, such speculationed chemoprotective properties require further experimental confirmation as no relevant assay in mammalian cells has been performed.

\section{Conclusions}

Marine organisms have proven to be a very rich source of natural molecules possessing various biological activities. Among others, the cancer-preventive activity has attracted a lot of attention in recent decades. Over the last nine years, thirty four marine-derived compounds have been reported to exhibit chemopreventive properties. For some of these compounds the cancer-preventive activity in other models has been previously described. Overall, the absolute number on the molecules for which the above-mentioned activity has been reported for the very first time has reduced. At the same time, a significant number of the molecules for which the cancer-preventive properties have previously been described were further investigated over the past years. Furthermore, the main research priority has been shifted to compounds found in edible sources, for example, the properties of carotenoids and polysaccharides found in marine algae were extensively studied recently. Of note, the reported mechanisms of cancer-preventive activities were often related to their anti-inflammatory, anti-ROS or free-radical scavenging, anti-angiogenetic, and immunomodulatory activities. Additionally, several compounds have demonstrated an ability to inhibit the carcinogen-activating phase I enzymes (cytochromes p450) and simultaneously increase the activity of phase II enzymes, which was revealed to be beneficial for carcinogen detoxification. Finally, for several compounds, their apoptosis-inducing activity was suggested to be responsible for their cancer-preventive properties, which were executed via elimination of malignant transformed cells or cancer stem cells. Overall, marine natural compounds, and in particular those found in edible marine organisms, have much potential as chemopreventive agents, and could be consumed as part of a daily diet. Therefore, further studies of their activity and mechanisms of action utilizing various biological models should highlight the most potent and promising molecules for the development of new drugs and food additives.

Funding: This study was supported by the Ministry of Science and Higher Education, Russian Federation (grant 13.1902.21.0012; contract No 075-15-2020-796).

Acknowledgments: The author would like to thank Viktoriya Levitskaya (Queen Mary University of London) for English proofreading and editing.

Conflicts of Interest: The author declare no conflict of interest.

\section{References}

1. Malarkey, D.E.; Hoenerhoff, M.; Maronpot, R.R. Chapter 5-Carcinogenesis: Mechanisms and Manifestations. In Haschek and Rousseaux's Handbook of Toxicologic Pathology, 3rd ed.; Haschek, W.M., Rousseaux, C.G., Wallig, M.A., Eds.; Academic Press: Boston, MA, USA, 2013; pp. 107-146.

2. Ferlay, J.; Colombet, M.; Soerjomataram, I.; Parkin, D.M.; Piñeros, M.; Znaor, A.; Bray, F. Cancer statistics for the year 2020: An overview. Int. J. Cancer 2021, 149, 778-789. [CrossRef] [PubMed]

3. Siegel, R.L.; Miller, K.D.; Fuchs, H.E.; Jemal, A. Cancer Statistics, 2021. CA. Cancer J. Clin. 2021, 71, 7-33. [CrossRef] [PubMed] 
4. Dagogo-Jack, I.; Shaw, A.T. Tumour heterogeneity and resistance to cancer therapies. Nat. Rev. Clin. Oncol. 2018, 15, 81-94. [CrossRef]

5. Zhong, L.; Li, Y.; Xiong, L.; Wang, W.; Wu, M.; Yuan, T.; Yang, W.; Tian, C.; Miao, Z.; Wang, T.; et al. Small molecules in targeted cancer therapy: Advances, challenges, and future perspectives. Signal Transduct. Target. Ther. 2021, 6, 201. [CrossRef] [PubMed]

6. Dyshlovoy, S.A.; Honecker, F. Marine Compounds and Cancer: The First Two Decades of XXI Century. Mar. Drugs 2019, 18, 20. [CrossRef]

7. Dyshlovoy, S.A.; Honecker, F. Marine Compounds and Cancer: Where Do We Stand? Mar. Drugs 2015, 13, 5657-5665. [CrossRef]

8. Mayer, A.M.S.; Guerrero, A.J.; Rodríguez, A.D.; Taglialatela-Scafati, O.; Nakamura, F.; Fusetani, N. Marine Pharmacology in 20162017: Marine Compounds with Antibacterial, Antidiabetic, Antifungal, Anti-Inflammatory, Antiprotozoal, Antituberculosis and Antiviral Activities; Affecting the Immune and Nervous Systems, and Other Miscellaneous Mechanisms of Action. Mar. Drugs 2021, 19, 49.

9. Mayer, A.M.S.; Guerrero, A.J.; Rodríguez, A.D.; Taglialatela-Scafati, O.; Nakamura, F.; Fusetani, N. Marine Pharmacology in 2014-2015: Marine Compounds with Antibacterial, Antidiabetic, Antifungal, Anti-Inflammatory, Antiprotozoal, Antituberculosis, Antiviral, and Anthelmintic Activities; Affecting the Immune and Nervous Systems, and Other Miscellaneous Mechanisms of Action. Mar. Drugs 2020, 18, 5 .

10. Brunt, E.G.; Burgess, J.G. The promise of marine molecules as cosmetic active ingredients. Int. J. Cosmet. Sci. 2018, 40, 1-15. [CrossRef]

11. Dyshlovoy, S.A.; Honecker, F. Marine Compounds and Cancer: Updates 2020. Mar. Drugs 2020, 18, 643. [CrossRef]

12. Mayer, A. Marine Pharmaceutical: Approved Marine Drugs. Available online: https://www.marinepharmacology.org/approved (accessed on 29 August 2021).

13. Suleria, H.A.R.; Osborne, S.; Masci, P.; Gobe, G. Marine-Based Nutraceuticals: An Innovative Trend in the Food and Supplement Industries. Mar. Drugs 2015, 13, 6336-6351. [CrossRef] [PubMed]

14. Mimouni, V.; Ulmann, L.; Haimeur, A.; Guéno, F.; Meskini, N.; Tremblin, G. Marine microalgae used as food supplements and their implication in preventing cardiovascular diseases. OCL 2015, 22, D409. [CrossRef]

15. Spanò, V.; Rocca, R.; Barreca, M.; Giallombardo, D.; Montalbano, A.; Carbone, A.; Raimondi, M.V.; Gaudio, E.; Bortolozzi, R.; Bai, R.; et al. Pyrrolo[2', 3':3,4]cyclohepta[1,2-d][1,2]oxazoles, a New Class of Antimitotic Agents Active against Multiple Malignant Cell Types. J. Med. Chem. 2020, 63, 12023-12042. [CrossRef]

16. Spanò, V.; Barreca, M.; Rocca, R.; Bortolozzi, R.; Bai, R.; Carbone, A.; Raimondi, M.V.; Piccionello, A.P.; Montalbano, A.; Alcaro, S.; et al. Insight on [1,3]thiazolo[4,5-e]isoindoles as tubulin polymerization inhibitors. Eur. J. Med. Chem. 2021, 212,113122 [CrossRef] [PubMed]

17. Barreca, M.; Spanò, V.; Raimondi, M.V.; Tarantelli, C.; Spriano, F.; Bertoni, F.; Barraja, P.; Montalbano, A. Recurrence of the oxazole motif in tubulin colchicine site inhibitors with anti-tumor activity. Eur. J. Med. Chem. Rep. 2021, 1, 100004.

18. Li Petri, G.; Spanò, V.; Spatola, R.; Holl, R.; Raimondi, M.V.; Barraja, P.; Montalbano, A. Bioactive pyrrole-based compounds with target selectivity. Eur. J. Med. Chem. 2020, 208, 112783. [CrossRef]

19. Barreca, M.; Spanò, V.; Montalbano, A.; Cueto, M.; Díaz Marrero, A.R.; Deniz, I.; Erdoğan, A.; Lukić Bilela, L.; Moulin, C.; Taffin-de-Givenchy, E.; et al. Marine Anticancer Agents: An Overview with a Particular Focus on Their Chemical Classes. Mar. Drugs 2020, 18, 619. [CrossRef]

20. Schwingshackl, L.; Morze, J.; Hoffmann, G. Mediterranean diet and health status: Active ingredients and pharmacological mechanisms. Br. J. Pharmacol. 2020, 177, 1241-1257. [CrossRef]

21. Correia-da-Silva, M.; Sousa, E.; Pinto, M.M.M.; Kijjoa, A. Anticancer and cancer preventive compounds from edible marine organisms. Semin. Cancer Biol. 2017, 46, 55-64. [CrossRef]

22. Hull, M.A.; Sprange, K.; Hepburn, T.; Tan, W.; Shafayat, A.; Rees, C.J.; Clifford, G.; Logan, R.F.; Loadman, P.M.; Williams, E.A.; et al. Eicosapentaenoic acid and/or aspirin for preventing colorectal adenomas during colonoscopic surveillance in the NHS Bowel Cancer Screening Programme: The seAFOod RCT. Lancet 2019, 6, 4. [CrossRef]

23. Galasso, C.; Gentile, A.; Orefice, I.; Ianora, A.; Bruno, A.; Noonan, D.M.; Sansone, C.; Albini, A.; Brunet, C. Microalgal Derivatives as Potential Nutraceutical and Food Supplements for Human Health: A Focus on Cancer Prevention and Interception. Nutrients 2019, 11, 1226. [CrossRef]

24. Wu, S.; Feng, B.; Li, K.; Zhu, X.; Liang, S.; Liu, X.; Han, S.; Wang, B.; Wu, K.; Miao, D.; et al. Fish consumption and colorectal cancer risk in humans: A systematic review and meta-analysis. Am. J. Med. 2012, 125, 551-559. [CrossRef]

25. Wen, J.; Hu, C.; Fan, S. Chemical composition and nutritional quality of sea cucumbers. J. Sci. Food Agric. 2010, 90, 2469-2474. [CrossRef]

26. Fabinyi, M. Historical, cultural and social perspectives on luxury seafood consumption in China. Environ. Conserv. 2012, 39, 83-92. [CrossRef]

27. Stonik, V.; Fedorov, S. Marine low molecular weight natural products as potential cancer preventive compounds. Mar. Drugs 2014, 12, 636-671. [CrossRef] [PubMed]

28. Cirkel, G.A.; Hooijdonk, C.G.G.-v.; Koudijs, M.J.; Willems, S.M.; Voest, E.E. Tumor heterogeneity and personalized cancer medicine: Are we being outnumbered? Future Oncol. 2014, 10, 417-428. [CrossRef]

29. Longo, D.L. Tumor Heterogeneity and Personalized Medicine. New Engl. J. Med. 2012, 366, 956-957. [CrossRef] [PubMed] 
30. Turajlic, S.; Sottoriva, A.; Graham, T.; Swanton, C. Resolving genetic heterogeneity in cancer. Nat. Rev. Genet. 2019, 20 , 404-416. [CrossRef]

31. Weston, A.; Harris, C.C. Multistage Carcinogenesis. In Holland-Frei Cancer Medicine, 6th ed.; Kufe, D.W., Pollock, R.E., Weichselbaum, R.R., Eds.; BC Decker: Hamilton, ON, USA, 2003.

32. Jones, P.A.; Baylin, S.B. The fundamental role of epigenetic events in cancer. Nat. Rev. Genet. 2002, 3, 415-428. [CrossRef]

33. Fujiki, H.; Sueoka, E.; Suganuma, M. Tumor promoters: From chemicals to inflammatory proteins. J. Cancer Res. Clin. Oncol. 2013, 139, 1603-1614. [CrossRef]

34. Luch, A. Nature and nurture-lessons from chemical carcinogenesis. Nat. Rev. Cancer 2005, 5, 113-125. [CrossRef]

35. Burchiel, S.W.; Thompson, T.A.; Lauer, F.T.; Oprea, T.I. Activation of dioxin response element (DRE)-associated genes by benzo(a)pyrene 3,6-quinone and benzo(a)pyrene 1,6-quinone in MCF-10A human mammary epithelial cells. Toxicol. Appl. Pharmacol. 2007, 221, 203-214. [CrossRef]

36. Lengauer, C.; Kinzler, K.W.; Vogelstein, B. Genetic instabilities in human cancers. Nature 1998, 396, 643-649. [CrossRef]

37. World Health Organization reports. Cancer. Available online: https://www.who.int/news-room/fact-sheets/detail/cancer (accessed on 5 September 2021).

38. Pan, M.-H.; Lai, C.-S.; Wu, J.-C.; Ho, C.-T. Molecular mechanisms for chemoprevention of colorectal cancer by natural dietary compounds. Mol. Nutr. Food Res. 2011, 55, 32-45. [CrossRef]

39. William, W.N.; Heymach, J.V.; Kim, E.S.; Lippman, S.M. Molecular targets for cancer chemoprevention. Nat. Rev. Drug Discov. 2009, 8, 213-225. [CrossRef]

40. Surh, Y.-J. Cancer chemoprevention with dietary phytochemicals. Nat. Rev. Cancer 2003, 3, 768-780. [CrossRef]

41. Iyanagi, T. Molecular Mechanism of Phase I and Phase II Drug-Metabolizing Enzymes: Implications for Detoxification. Int. Rev. Cytol. 2007, 260, 35-112.

42. Smith, C.A.D.; Smith, G.; Wolf, C.R. Genetic polymorphisms in xenobiotic metabolism. Eur. J. Cancer 1994, 30, 1921-1935. [CrossRef]

43. Turesky, R.J. The role of genetic polymorphisms in metabolism of carcinogenic heterocyclic aromatic amines. Curr Drug Metab 2004, 5, 169-180. [CrossRef] [PubMed]

44. Guengerich, F.P. Metabolism of chemical carcinogens. Carcinogenesis 2000, 21, 345-351. [CrossRef] [PubMed]

45. Brockstedt, U.; Krajinovic, M.; Richer, C.; Mathonnet, G.; Sinnett, D.; Pfau, W.; Labuda, D. Analyses of bulky DNA adduct levels in human breast tissue and genetic polymorphisms of cytochromes P450 (CYPs), myeloperoxidase (MPO), quinone oxidoreductase (NQO1), and glutathione S-transferases (GSTs). Mutat. Res. 2002, 516, 41-47. [CrossRef]

46. Ahn, J.-H.; Yang, Y.-I.; Lee, K.-T.; Choi, J.-H. Dieckol, isolated from the edible brown algae Ecklonia cava, induces apoptosis of ovarian cancer cells and inhibits tumor xenograft growth. J. Cancer Res. Clin. Oncol. 2015, 141, 255-268. [CrossRef]

47. Li, Y.; Qian, Z.J.; Ryu, B.; Lee, S.H.; Kim, M.M.; Kim, S.K. Chemical components and its antioxidant properties in vitro: An edible marine brown alga, Ecklonia cava. Bioorg. Med. Chem. 2009, 17, 1963-1973. [CrossRef]

48. Lee, J.H.; Kim, N.D.; Choi, J.S.; Kim, Y.J.; Heo, M.Y.; Lim, S.Y.; Park, K.Y. Inhibitory Effects of the Methanolic Extract of an Edible Brown Alga, Ecklonia stolonifera and Its Component, Phloroglucinol on Aflatoxin B1 Mutagenicity In Vitro (Ames Test) and on Benzo(a)pyrene or N-Methyl N-nitrosourea Clastogenicity In Vivo (Mouse Micronucleus Test). Nat. Prod. Sci. 1998, 4, 105-114.

49. Lee, J.H.; Oh, H.Y.; Park, J.S. Preventive Effect of Ecklonia Stolonifera on the Frequency of Benzo(a)pyrene-Induced Chromosomal Aberrations. Nat. Prod. Sci. 1996, 1, 64-68.

50. Hwang, H.; Chen, T.; Nines, R.G.; Shin, H.-C.; Stoner, G.D. Photochemoprevention of UVB-induced skin carcinogenesis in SKH-1 mice by brown algae polyphenols. Int. J. Cancer 2006, 119, 2742-2749. [CrossRef]

51. Xiao, W.; Liu, H.; Lei, Y.; Gao, H.; Alahmadi, T.A.; Peng, H.; Chen, W. Chemopreventive effect of dieckol against 7,12dimethylbenz(a)anthracene induced skin carcinogenesis model by modulatory influence on biochemical and antioxidant biomarkers. Environ. Toxicol. 2021, 36, 800-810. [CrossRef] [PubMed]

52. Kang, M.C.; Ahn, G.; Yang, X.; Kim, K.N.; Kang, S.M.; Lee, S.H.; Ko, S.C.; Ko, J.Y.; Kim, D.; Kim, Y.T.; et al. Hepatoprotective effects of dieckol-rich phlorotannins from Ecklonia cava, a brown seaweed, against ethanol induced liver damage in BALB/c mice. Food Chem. Toxicol. 2012, 50, 1986-1991. [CrossRef]

53. Li, S.; Liu, J.; Zhang, M.; Chen, Y.; Zhu, T.; Wang, J. Protective Effect of Eckol against Acute Hepatic Injury Induced by Carbon Tetrachloride in Mice. Mar. Drugs 2018, 16, 300. [CrossRef] [PubMed]

54. Kang, M.-C.; Kang, S.-M.; Ahn, G.; Kim, K.-N.; Kang, N.; Samarakoon, K.W.; Oh, M.-C.; Lee, J.-S.; Jeon, Y.-J. Protective effect of a marine polyphenol, dieckol against carbon tetrachloride-induced acute liver damage in mouse. Environ. Toxicol. Pharmacol. 2013, 35, 517-523. [CrossRef] [PubMed]

55. Lin, L.; Yang, S.; Xiao, Z.; Hong, P.; Sun, S.; Zhou, C.; Qian, Z.-J. The Inhibition Effect of the Seaweed Polyphenol, 7-Phloro-Eckol from Ecklonia Cava on Alcohol-Induced Oxidative Stress in HepG2/CYP2E1 Cells. Mar. Drugs 2021, 19, 158. [CrossRef]

56. Sadeeshkumar, V.; Duraikannu, A.; Ravichandran, S.; Kodisundaram, P.; Fredrick, W.S.; Gobalakrishnan, R. Modulatory efficacy of dieckol on xenobiotic-metabolizing enzymes, cell proliferation, apoptosis, invasion and angiogenesis during NDEA-induced rat hepatocarcinogenesis. Mol. Cell. Biochem. 2017, 433, 195-204. [CrossRef]

57. Rajamani, K.; Thirugnanasambandan, S.S.; Natesan, C.; Subramaniam, S.; Thangavel, B.; Aravindan, N. Squalene deters drivers of RCC disease progression beyond VHL status. Cell Biol. Toxicol. 2021, 37, 611-631. [CrossRef] 
58. Rajamani, K.; Thirugnanasambandan, S.S. Polyphenols from brown alga, Padina boergesenii (Allendar \& Kraft) decelerates renal cancer growth involving cell cycle arrest and induction of apoptosis in renal carcinoma cells. Environ. Toxicol. 2018, 33, 1135-1142. [PubMed]

59. Lou-Bonafonte, J.M.; Martínez-Beamonte, R.; Sanclemente, T.; Surra, J.C.; Herrera-Marcos, L.V.; Sanchez-Marco, J.; Arnal, C.; Osada, J. Current Insights into the Biological Action of Squalene. Mol. Nutr. Food Res. 2018, 62, 1800136. [CrossRef]

60. Jiao, L.; Weinstein, S.J.; Albanes, D.; Taylor, P.R.; Graubard, B.I.; Virtamo, J.; Stolzenberg-Solomon, R.Z. Evidence that serum levels of the soluble receptor for advanced glycation end products are inversely associated with pancreatic cancer risk: A prospective study. Cancer Res. 2011, 71, 3582-3589. [CrossRef] [PubMed]

61. Guzmán, E.A.; Pitts, T.P.; Diaz, M.C.; Wright, A.E. The marine natural product Scalarin inhibits the receptor for advanced glycation end products (RAGE) and autophagy in the PANC-1 and MIA PaCa-2 pancreatic cancer cell lines. Invest. New Drugs 2019, 37, 262-270. [CrossRef] [PubMed]

62. Sims, G.P.; Rowe, D.C.; Rietdijk, S.T.; Herbst, R.; Coyle, A.J. HMGB1 and RAGE in inflammation and cancer. Annu. Rev. Immunol. 2010, 28, 367-388. [CrossRef] [PubMed]

63. Guzii, A.G.; Makarieva, T.N.; Denisenko, V.A.; Dmitrenok, P.S.; Popov, R.S.; Kuzmich, A.S.; Fedorov, S.N.; Krasokhin, V.B.; Kim, N.Y.; Stonik, V.A. Melonoside B and Melonosins A and B, Lipids Containing Multifunctionalized $\omega$-Hydroxy Fatty Acid Amides from the Far Eastern Marine Sponge Melonanchora kobjakovae. J. Nat. Prod. 2018, 81, 2763-2767. [CrossRef]

64. Dhar, A.; Young, M.R.; Colburn, N.H. The role of AP-1, NF- $\mathrm{BB}$ and ROS/NOS in skin carcinogenesis: The JB6 model is predictive. Mol. Cell. Biochem. 2002, 234, 185-193. [CrossRef]

65. Wang, R.; Paul, V.J.; Luesch, H. Seaweed extracts and unsaturated fatty acid constituents from the green alga Ulva lactuca as activators of the cytoprotective Nrf2-ARE pathway. Free Radic. Biol. Med. 2013, 57, 141-153. [CrossRef]

66. Keum, Y.S. Regulation of Nrf2-Mediated Phase II Detoxification and Anti-oxidant Genes. Biomol. Ther. 2012, 20, 144-151. [CrossRef]

67. Li, J.; Li, K.; Gao, J.; Guo, X.; Lu, M.; Li, Z.; Li, D. Maternal exposure to an n-3 polyunsaturated fatty acid diet decreases mammary cancer risk of female offspring in adulthood. Food Funct 2018, 9, 5768-5777. [CrossRef] [PubMed]

68. Shai, Y. Pardaxin: Channel formation by a shark repellant peptide from fish. Toxicology 1994, 87, 109-129. [CrossRef]

69. Han, Y.; Cui, Z.; Li, Y.-H.; Hsu, W.-H.; Lee, B.-H. In Vitro and in Vivo Anticancer Activity of Pardaxin against Proliferation and Growth of Oral Squamous Cell Carcinoma. Mar. Drugs 2016, 14, 2. [CrossRef] [PubMed]

70. Piplani, H.; Rana, C.; Vaish, V.; Vaiphei, K.; Sanyal, S.N. Dolastatin, along with Celecoxib, stimulates apoptosis by a mechanism involving oxidative stress, membrane potential change and PI3-K/AKT pathway down regulation. Biochim. Biophys. Acta (BBA)-Gen. Subj. 2013, 1830, 5142-5156. [CrossRef] [PubMed]

71. Piplani, H.; Vaish, V.; Rana, C.; Sanyal, S.N. Up-regulation of p53 and mitochondrial signaling pathway in apoptosis by a combination of cox-2 inhibitor, celecoxib and dolastatin 15, a marine mollusk linear peptide in experimental colon carcinogenesis. Mol. Carcinog. 2013, 52, 845-858. [CrossRef] [PubMed]

72. Peng, J.; Yuan, J.-P.; Wu, C.-F.; Wang, J.-H. Fucoxanthin, a Marine Carotenoid Present in Brown Seaweeds and Diatoms: Metabolism and Bioactivities Relevant to Human Health. Mar. Drugs 2011, 9, 1806-1828. [CrossRef]

73. Terasaki, M.; Uehara, O.; Ogasa, S.; Sano, T.; Kubota, A.; Kojima, H.; Tanaka, T.; Maeda, H.; Miyashita, K.; Mutoh, M. Alteration of fecal microbiota by fucoxanthin results in prevention of colorectal cancer in AOM/DSS mice. Carcinogenesis 2020, 42, 210-219. [CrossRef]

74. Terasaki, M.; Maeda, H.; Miyashita, K.; Tanaka, T.; Miyamoto, S.; Mutoh, M. A marine bio-functional lipid, fucoxanthinol, attenuates human colorectal cancer stem-like cell tumorigenicity and sphere formation. J. Clin. Biochem. Nutr. 2017, 61, 25-32. [CrossRef]

75. Hashimoto, T.; Ozaki, Y.; Mizuno, M.; Yoshida, M.; Nishitani, Y.; Azuma, T.; Komoto, A.; Maoka, T.; Tanino, Y.; Kanazawa, K. Pharmacokinetics of fucoxanthinol in human plasma after the oral administration of kombu extract. Br. J. Nutr. 2012, 107, 1566-1569. [CrossRef]

76. Zhou, H.-M.; Zhang, J.-G.; Zhang, X.; Li, Q. Targeting cancer stem cells for reversing therapy resistance: Mechanism, signaling, and prospective agents. Signal Transduct. Target. Ther. 2021, 6, 62. [CrossRef]

77. Li, Y.; Wicha, M.S.; Schwartz, S.J.; Sun, D. Implications of cancer stem cell theory for cancer chemoprevention by natural dietary compounds. J. Nutr. Biochem. 2011, 22, 799-806. [CrossRef]

78. Terasaki, M.; Nishizaka, Y.; Murase, W.; Kubota, A.; Kojima, H.; Kojoma, M.; Tanaka, T.; Maeda, H.; Miyashita, K.; Mutoh, M.; et al. Effect of Fucoxanthinol on Pancreatic Ductal Adenocarcinoma Cells from an N-Nitrosobis(2-oxopropyl)amine-initiated Syrian Golden Hamster Pancreatic Carcinogenesis Model. Cancer Genom. Proteom. 2021, 18 (Suppl. S3), 407-423. [CrossRef] [PubMed]

79. Terasaki, M.; Iida, T.; Kikuchi, F.; Tamura, K.; Endo, T.; Kuramitsu, Y.; Tanaka, T.; Maeda, H.; Miyashita, K.; Mutoh, M. Fucoxanthin potentiates anoikis in colon mucosa and prevents carcinogenesis in AOM/DSS model mice. J. Nutr. Biochem. 2019, 64, 198-205. [CrossRef] [PubMed]

80. Terasaki, M.; Ikuta, M.; Kojima, H.; Tanaka, T.; Maeda, H.; Miyashita, K.; Mutoh, M. Dietary Fucoxanthin Induces Anoikis in Colorectal Adenocarcinoma by Suppressing Integrin Signaling in a Murine Colorectal Cancer Model. J. Clin. Med. 2020, 9, 90. [CrossRef] [PubMed] 
81. Ambati, R.R.; Phang, S.-M.; Ravi, S.; Aswathanarayana, R.G. Astaxanthin: Sources, Extraction, Stability, Biological Activities and Its Commercial Applications-A Review. Mar. Drugs 2014, 12, 128-152. [CrossRef] [PubMed]

82. Han, H.; Lim, J.W.; Kim, H. Astaxanthin Inhibits Helicobacter pylori-induced Inflammatory and Oncogenic Responses in Gastric Mucosal Tissues of Mice. J. Cancer Prev. 2020, 25, 244-251.

83. Peek, R.M.; Blaser, M.J. Helicobacter pylori and gastrointestinal tract adenocarcinomas. Nat. Rev. Cancer 2002, 2, 28-37. [CrossRef]

84. Srinivasan, R.; Chaitanyakumar, A.; Mageswari, A.; Gomathi, A.; Pavan Kumar, J.G.S.; Jayasindu, M.; Bharath, G.; Shravan, J.S.; Gothandam, K.M. Oral administration of lyophilized Dunaliella salina, a carotenoid-rich marine alga, reduces tumor progression in mammary cancer induced rats. Food Funct. 2017, 8, 4517-4527. [CrossRef]

85. Carlson, S.; Marler, L.; Nam, S.-J.; Santarsiero, B.D.; Pezzuto, J.M.; Murphy, B.T. Potential Chemopreventive Activity of a New Macrolide Antibiotic from a Marine-Derived Micromonospora sp. Mar. Drugs 2013, 11, 1152-1161. [CrossRef]

86. Dinkova-Kostova, A.T.; Talalay, P. Persuasive evidence that quinone reductase type 1 (DT diaphorase) protects cells against the toxicity of electrophiles and reactive forms of oxygen. Free Radic. Biol. Med. 2000, 29, 231-240. [CrossRef]

87. Pettit, G.R.; Herald, C.L.; Doubek, D.L.; Herald, D.L.; Arnold, E.; Clardy, J. Isolation and structure of bryostatin 1. J. Am. Chem. Soc. 1982, 104, 6846-6848. [CrossRef]

88. Salim, E.I.; Harras, S.F.; Abdalla, A.G.; Mona, M.H. Syphacia muris infection in rats attenuates colorectal carcinogenesis through oxidative stress and gene expression alterations. Implications for modulatory effects by Bryostatin-1. Acta Parasitol. 2018, 63, 198-209. [CrossRef]

89. Du, Y.E.; Bae, E.S.; Lim, Y.; Cho, J.-C.; Nam, S.-J.; Shin, J.; Lee, S.K.; Nam, S.-I.; Oh, D.-C. Svalbamides A and B, PyrrolidinoneBearing Lipodipeptides from Arctic Paenibacillus sp. Mar. Drugs 2021, 19, 229. [CrossRef]

90. Park, S.; Kim, J.-H.; Kim, J.E.; Song, G.-Y.; Zhou, W.; Goh, S.-H.; Na, M.; Oh, S. Cytotoxic activity of aeroplysinin-1 against colon cancer cells by promoting $\beta$-catenin degradation. Food Chem. Toxicol. 2016, 93, 66-72. [CrossRef] [PubMed]

91. Fattorusso, E.; Minale, L.; Sodano, G. Aeroplysinin-1, an antibacterial bromo-compound from the sponge Verongia aerophoba. J. Chem. Soc. Perkin Trans. 1 1972, 1, 16-18. [CrossRef] [PubMed]

92. Takahashi, M.; Tsunoda, T.; Seiki, M.; Nakamura, Y.; Furukawa, Y. Identification of membrane-type matrix metalloproteinase-1 as a target of the $\beta$-catenin/Tcf4 complex in human colorectal cancers. Oncogene 2002, 21, 5861-5867. [CrossRef] [PubMed]

93. Tetsu, O.; McCormick, F. $\beta$-Catenin regulates expression of cyclin D1 in colon carcinoma cells. Nature 1999, 398, 422-426. [CrossRef]

94. He, T.-C.; Sparks, A.B.; Rago, C.; Hermeking, H.; Zawel, L.; da Costa, L.T.; Morin, P.J.; Vogelstein, B.; Kinzler, K.W. Identification of c-MYC as a Target of the APC Pathway. Science 1998, 281, 1509-1512. [CrossRef]

95. Esmaeelian, B.; Benkendorff, K.; Le Leu, R.K.; Abbott, C.A. Simultaneous Assessment of the Efficacy and Toxicity of Marine Mollusc-Derived Brominated Indoles in an In Vivo Model for Early Stage Colon Cancer. Integr. Cancer Ther. 2018, 17, $248-262$. [CrossRef]

96. Esmaeelian, B.; Benkendorff, K.; Johnston, M.R.; Abbott, C.A. Purified Brominated Indole Derivatives from Dicathais orbita Induce Apoptosis and Cell Cycle Arrest in Colorectal Cancer Cell Lines. Mar. Drugs 2013, 11, 3802-3822. [CrossRef]

97. Neufert, C.; Becker, C.; Neurath, M.F. An inducible mouse model of colon carcinogenesis for the analysis of sporadic and inflammation-driven tumor progression. Nat. Protoc. 2007, 2, 1998-2004. [CrossRef]

98. Hwang, J.; Kim, D.; Park, J.S.; Park, H.J.; Shin, J.; Lee, S.K. Photoprotective Activity of Topsentin, A Bis(Indole) Alkaloid from the Marine Sponge Spongosorites genitrix, by Regulation of COX-2 and Mir-4485 Expression in UVB-Irradiated Human Keratinocyte Cells. Mar. Drugs 2020, 18, 87. [CrossRef] [PubMed]

99. Shin, J.; Seo, Y.; Cho, K.W.; Rho, J.-R.; Sim, C.J. New Bis(Indole) Alkaloids of the Topsentin Class from the Sponge Spongosorites genitrix. J. Nat. Prod. 1999, 62, 647-649. [CrossRef]

100. Liu, G.; Chen, N.; Kaji, A.; Bode, A.M.; Ryan, C.A.; Dong, Z. Proteinase inhibitors I and II from potatoes block UVB-induced AP-1 activity by regulating the AP-1 protein compositional patterns in JB6 cells. Proc. Natl. Acad. Sci. USA 2001, 98, 5786-5791. [CrossRef]

101. Angel, P.; Imagawa, M.; Chiu, R.; Stein, B.; Imbra, R.J.; Rahmsdorf, H.J.; Jonat, C.; Herrlich, P.; Karin, M. Phorbol ester-inducible genes contain a common cis element recognized by a TPA-modulated trans-acting factor. Cell 1987, 49, 729-739. [CrossRef]

102. Kang, N.J.; Lee, K.W.; Kwon, J.Y.; Hwang, M.K.; Rogozin, E.A.; Heo, Y.S.; Bode, A.M.; Lee, H.J.; Dong, Z. Delphinidin attenuates neoplastic transformation in JB6 Cl41 mouse epidermal cells by blocking Raf/mitogen-activated protein kinase kinase/extracellular signal-regulated kinase signaling. Cancer Prev Res 2008, 1, 522-531. [CrossRef]

103. Pansanit, A.; Park, E.-J.; Kondratyuk, T.P.; Pezzuto, J.M.; Lirdprapamongkol, K.; Kittakoop, P. Vermelhotin, an Anti-inflammatory Agent, Suppresses Nitric Oxide Production in RAW 264.7 Cells via p38 Inhibition. J. Nat. Prod. 2013, 76, 1824-1827. [CrossRef] [PubMed]

104. Kasettrathat, C.; Ngamrojanavanich, N.; Wiyakrutta, S.; Mahidol, C.; Ruchirawat, S.; Kittakoop, P. Cytotoxic and antiplasmodial substances from marine-derived fungi, Nodulisporium sp. and CRI247-01. Phytochemistry 2008, 69, 2621-2626. [CrossRef] [PubMed]

105. Kokoulin, M.S.; Filshtein, A.P.; Romanenko, L.A.; Chikalovets, I.V.; Chernikov, O.V. Structure, antiproliferative and cancer preventive properties of sulfated $\alpha$-d-fucan from the marine bacterium Vadicella arenosi. Carbohydr. Polym. 2019, 221, 120-126. [CrossRef] 
106. Cmarik, J.L.; Colburn, N.H. Use of Mouse JB6 Cells to Identify Molecular Targets and Novel Agents for Prevention of Carcinogenesis, Food Factors for Cancer Prevention, Tokyo, 1997//; Ohigashi, H., Osawa, T., Terao, J., Watanabe, S., Yoshikawa, T., Eds.; Springer Japan: Tokyo, Japan, 1997; pp. 67-76.

107. Vishchuk, O.S.; Ermakova, S.P.; Zvyagintseva, T.N. The fucoidans from brown algae of Far-Eastern seas: Anti-tumor activity and structure-function relationship. Food Chem. 2013, 141, 1211-1217. [CrossRef] [PubMed]

108. Vishchuk, O.S.; Sun, H.; Wang, Z.; Ermakova, S.P.; Xiao, J.; Lu, T.; Xue, P.; Zvyagintseva, T.N.; Xiong, H.; Shao, C.; et al. PDZ-binding kinase/T-LAK cell-originated protein kinase is a target of the fucoidan from brown alga Fucus evanescens in the prevention of EGF-induced neoplastic cell transformation and colon cancer growth. Oncotarget 2016, 7, 18763-18773. [CrossRef] [PubMed]

109. Hussein, U.K.; Mahmoud, H.M.; Farrag, A.G.; Bishayee, A. Chemoprevention of Diethylnitrosamine-Initiated and PhenobarbitalPromoted Hepatocarcinogenesis in Rats by Sulfated Polysaccharides and Aqueous Extract of Ulva lactuca. Integr. Cancer 2015, 14, 525-545. [CrossRef] [PubMed]

110. Youn, U.J.; Sripisut, T.; Park, E.-J.; Kondratyuk, T.P.; Fatima, N.; Simmons, C.J.; Wall, M.M.; Sun, D.; Pezzuto, J.M.; Chang, L.C. Determination of the absolute configuration of chaetoviridins and other bioactive azaphilones from the endophytic fungus Chaetomium globosum. Biorg. Med. Chem. Lett. 2015, 25, 4719-4723. [CrossRef] [PubMed]

111. Silva, J.B.; Pereira, J.R.; Marreiros, B.C.; Reis, M.A.M.; Freitas, F. Microbial production of medium-chain length polyhydroxyalkanoates. Process Biochem. 2021, 102, 393-407. [CrossRef]

112. Yamada, T.; Muroga, Y.; Jinno, M.; Kajimoto, T.; Usami, Y.; Numata, A.; Tanaka, R. New class azaphilone produced by a marine fish-derived Chaetomium globosum. The stereochemistry and biological activities. Bioorg. Med. Chem. 2011, 19, 4106-4113. [CrossRef]

113. Fatima, N.; Muhammad, S.A.; Khan, I.; Qazi, M.A.; Shahzadi, I.; Mumtaz, A.; Hashmi, M.A.; Khan, A.K.; Ismail, T. Chaetomium endophytes: A repository of pharmacologically active metabolites. Acta Physiol. Plant. 2016, 38, 136. [CrossRef]

114. Yasuhide, M.; Yamada, T.; Numata, A.; Tanaka, R. Chaetomugilins, New Selectively Cytotoxic Metabolites, Produced by a Marine Fish-derived Chaetomium Species. J. Antibiot. 2008, 61, 615-622. [CrossRef]

115. Bousquet, M.S.; Ratnayake, R.; Pope, J.L.; Chen, Q.-Y.; Zhu, F.; Chen, S.; Carney, T.J.; Gharaibeh, R.Z.; Jobin, C.; Paul, V.J.; et al Seaweed natural products modify the host inflammatory response via Nrf2 signaling and alter colon microbiota composition and gene expression. Free Radic. Biol. Med. 2020, 146, 306-323. [CrossRef]

116. Son, Y.S.; Ullah, H.M.A.; Elfadl, A.K.; Ghim, S.G.; Chung, M.J.; Kim, Y.D.; Lee, E.J.; Kang, K.K.; Jeong, K.S. Inhibition of Formation of Azoxymethane-induced Colonic Aberrant Crypt Foci in Rats by Edible Green Algae Capsosiphon fulvescens and Brown Algae Hizikia fusiforme. In Vivo 2018, 32, 101-108. [PubMed]

117. Osuna-Ruiz, I.; López-Saiz, C.-M.; Burgos-Hernández, A.; Velázquez, C.; Nieves-Soto, M.; Hurtado-Oliva, M.A. Antioxidant, antimutagenic and antiproliferative activities in selected seaweed species from Sinaloa, Mexico. Pharm. Biol. 2016, 54, $2196-2210$. [CrossRef] [PubMed]

118. Osuna-Ruiz, I.; Nieves-Soto, M.; Manzano-Sarabia, M.M.; Hernández-Garibay, E.; Lizardi-Mendoza, J.; Burgos-Hernández, A.; Hurtado-Oliva, M.Á. Gross chemical composition, fatty acids, sterols, and pigments in tropical seaweed species off Sinaloa, Mexico. Cienc. Mar. 2019, 45, 101-120. [CrossRef]

119. Hernández-Zazueta, M.S.; García-Romo, J.S.; Noguera-Artiaga, L.; Luzardo-Ocampo, I.; Carbonell-Barrachina, Á.A.; TaboadaAntelo, P.; Campos-Vega, R.; Rosas-Burgos, E.C.; Burboa-Zazueta, M.G.; Ezquerra-Brauer, J.M.; et al. Octopus vulgaris ink extracts exhibit antioxidant, antimutagenic, cytoprotective, antiproliferative, and proapoptotic effects in selected human cancer cell lines. J. Food Sci. 2021, 86, 587-601. [CrossRef]

120. Cruz-Ramírez, S.G.; López-Saiz, C.M.; Rosas-Burgos, E.C.; Cinco-Moroyoqui, F.J.; Velázquez, C.; Hernández, J.; BurgosHernández, A. Antimutagenic, antiproliferative, and antioxidant effect of extracts obtained from octopus (Paraoctopus limaculatus). Food Sci. Technol. 2015, 35, 722-728. [CrossRef] 